\title{
Krzysztof Szymanek
}

Uniwersytet Śląski w Katowicach

(D) https://orcid.org/0000-0002-2817-2651

\section{Erystyka, moralność i wojna}

\author{
Eristic, Morality, and War
}

\begin{abstract}
The article addresses the ethical aspects of eristic and - more generally - the difficulties people encounter while evaluating debates in moral terms. Simplified and superficial ways to perceive eristical phenomena lead to inadequate assessments. Krzysztof Szymanek objects to the stereotype of eristic as the art of unfair debating and argues that eristical stratagems cannot be considered simpliciter as honest or dishonest without taking into account the circumstances under which arguments are exchanged. He gives and discusses examples of argumentative moves which, on the one hand, are deceptive, but, on the other, lead to the victory of what is right. A comparison of eristical fights to military battles helps to highlight the difficulties in formulating moral judgments about disputes.
\end{abstract}

Keywords: dialectic, eristic, ethics, manipulation, persuasion

\section{Wprowadzenie}

1. Rozważania zawarte $\mathrm{w}$ artykule należą do tego obszaru, który Arystoteles zaliczał do filozofii praktycznej, włączywszy w to zagadnienia retoryki czy dialektyki. Celem jest krytyczne rozpatrzenie stereotypu erystyki jako sztuki nieuczciwego dyskutowania oraz ukazanie trudności, jakie napotykamy, gdy próbujemy stosować kategorie moralne w dziedzinie praktyki argumentacji, gdzie uproszczone, płytkie postrzeganie zjawisk często 
prowadzi do wydawania nieadekwatnych i krzywdzących ocen etycznych. Staramy się uwyraźnić niektóre zjawiska $\mathrm{z}$ tego pola poprzez porównanie walki erystycznej do zmagań wojennych.

2. W życiu intelektualnym starożytnej Grecji, kolebce europejskiej kultury, wielkim poważaniem cieszyła się sztuka roztrząsania spornych problemów na drodze dialogu, zwana dialektyką. Odwołując się do współczesnych pojęć, powiedzielibyśmy, że dialektyka dla Greków była sztuką dyskutowania zarówno zagadnień filozoficznych i naukowych, jak i tych z obszaru życia społecznego, ze sfery polityki i moralności'. Z założenia miała służyć zbliżeniu się do prawdy, pogłębieniu i rozwinięciu wiedzy na drodze krytycznego, uporządkowanego omówienia stanowisk, wyszczególnieniu i rozpatrzeniu wszystkich ,za” i ,przeciw”, zderzeniu wysuwanych w danej sprawie argumentów. Zakresem badań dialektyka obejmowała formalne reguły dyskutowania, metody wynajdywania argumentów, sposoby ich przedkładania, jak i odpierania, wszelkiego rodzaju strategie i chwyty polemiczne, a także zagadnienia, które obecnie zaliczylibyśmy do logiki, na przykład kwestię poprawności wnioskowania czy błędy rozumowania. W toku historii termin „dialektyka” był stosowany zamiennie z terminem „logika”.

3. Chociaż dialektyka czy logika miały stanowić oręż prawdy i słuszności, już w najdawniejszych czasach wiadomo było dobrze, że dyskusja może być wykorzystywana do mniej szlachetnych celów i w mniej szlachetny sposób. Jak możemy zaobserwować, nieraz dyskutanci tylko pozornie zabiegają o wydobycie na wierzch prawdy, a w rzeczywistości chodzi im przede wszystkim o wykazanie, że słuszne jest właśnie to stanowisko, które oni zajmują, a inni się mylą. Godzą się na to, by w dyskusji zwyciężył pogląd $\mathrm{w}$ istocie źle uzasadniony, nawet fałszywy, byle to był ich pogląd. Zapędy takie wypływają z rozmaitych pobudek: może to być zwykła ambicja posiadania racji i wykazania swojej wyższości, czasem jednak tło jest dużo szersze, nie chodzi tylko o psychologiczną potrzebę zdobycia czy utrzymania osobistego prestiżu. Za sporami stoją żywotne interesy, czasem o wymiarze ideologicznym, politycznym, światopoglądowym. Konflikty interesów w społeczeństwie z reguły na którymś z etapów przyjmują postać mniej lub bardziej uporządkowanej i sformalizowanej wymiany argumentów.

4. W Grecji używano słowa „erystyka” na oznaczenie niemoralnej, pozbawionej zasad sztuki wygrywania sporów słownych za pomocą gry pozorów i manipulacji. Erystyka miała być zepsutą siostrą dialektyki, podszywającą się jedynie pod prawą i szlachetną sztukę dochodzenia do prawdy.

${ }^{1}$ M. Spranzi: The Art of Dialectic between Dialogue and Rhetoric: The Aristotelian Tradition. John Benjamins Publishing Company, Amsterdam-Philadelphia 2011, s. 11-47; D. Walton: Dialog Theory for Critical Argumentation. John Benjamins Publishing Company, Amsterdam 2007, s. 47-62. 
Arystoteles w $O$ dowodach sofistycznych $171 \mathrm{~b}^{2}$ określa erystykę jako „,nieuczciwy sposób walki słownej”. „Erystyk - pisze filozof - ma się tak w pewnej mierze do dialektyka, jak rysujący fałszywe diagramy do geometry”. Erystykę na trwałe skojarzono z nieuczciwością, niskimi pobudkami, fałszem i manipulacją. Tak więc Arthur Schopenhauer „dialektyką erystyczną" nazywa „naukę o wrodzonej człowiekowi chęci, by zawsze mieć rację", jest to „sztuka dyskutowania w taki sposób, aby zachować pozory racji”. U korzeni skłonności erystycznych dostrzega zepsucie natury ludzkiej, wrodzoną nieuczciwość; ,gdybyśmy byli - pisze filozof - z gruntu uczciwi, tobyśmy się starali w każdym sporze tylko o to, aby dojść do prawdy, nie bacząc na to, czy zgadza się ona z naszym pierwotnie wygłoszonym zdaniem, czy też ze zdaniem przeciwnika"4. Douglas Walton charakteryzuje dialog erystyczny jako coś zbliżonego do kłótni ${ }^{5}$. Uczestnicy bardziej chcą ugodzić w osobę adwersarza niż w jego argumenty, a wyartykułowanie różnego rodzaju urazów i żalów staje się ważniejsze od racjonalnego rozstrzygnięcia sporu. Typowe jest użycie błędnych argumentów i zwodniczych taktyk. Choć uczestnicy mogą utrzymywać, że ich cel to prawda, o prawdę wszakże im nie chodzi.

Tadeusz Kotarbiński nie odmawia sztuce erystyki pewnej dozy „mądrości technicznej w połączeniu ze sprytem wzbudzającym słuszną odrazę" Przytacza przykłady technik erystycznych uczciwych - takich, które są „lojalne wobec przeciwnika” - obok tych chwytów, które prowadzą na grunt „Śliski moralnie”. Techniką lojalną jest, przykładowo, skupianie uwagi na tych twierdzeniach przeciwnika, które stanowią fundament jego stanowiska i atakowanie w pierwszej kolejności tych właśnie twierdzeń. Inny przykład to wysnuwanie korzystnych dla siebie wniosków z założeń, na których opiera się przeciwnik. Obok forteli lojalnych Kotarbiński wymienia też pewną liczbę tych, które naruszają normy uczciwości. Warto poznać i jedne, i drugie, gdyż „trzeba wiedzieć, jak można pomóc sobie lojalnie w obronie słusznej sprawy i na co się może zdobyć nielojalny sprytny przeciwnik"’.

${ }^{2}$ Arystoteles: O dowodach sofistycznych. W: Idem: Dzieła wszystkie. T. 1: Kategorie; Hermeneutyka; Analityki pierwsze; Analityki wtóre; Topiki; O dowodach sofistycznych. Przekł., wstępy i komentarze K. Leśniak. Wyd. 2. Wydawnictwo Naukowe PWN, Warszawa 2003, s. 476-518.

3 A. Schopenhauer: Erystyka, czyli sztuka prowadzenia sporów. Przeł. z niem. B. Konorski, Ł. Konorska. Przedmowa T. Kotarbiński. Wydawnictwo Literackie, Kraków 1973, s. 24-25.

${ }^{4}$ Ibidem, s. 26.

${ }^{5}$ D. Walton: Dialog Theory for Critical Argumentation..., s. 116.

${ }^{6}$ T. Kotarbiński: Logika dla prawników. W: Idem: Ontologia, teoria poznania i metodologia nauk. Zakład Narodowy im. Ossolińskich, Wydawnictwo, Wrocław 1993, s. 418.

${ }^{7}$ Ibidem, s. 415. 
5. Kotarbiński przedstawia też ideał „dyskusji rzeczowej”, w której „obie strony rzetelnie dążą do wyświetlenia prawdy"8. Postulaty Kotarbińskiego odpowiadają obrazowi racjonalnej dyskusji, który znajdujemy też u innych autorów9. Uczestnicy takiej wymiany myśli traktują dialog jako wspólne poszukiwanie prawdy - a przenika ich bezinteresowne pragnienie poznania prawdy dla niej samej. Nie kierują się żadnymi osobistymi pobudkami, nie są ambicjonalnie związani ze swoimi poglądami, przeciwnie: wykazują gotowość do ich odrzucenia w chwili, gdy przedstawiono przeciw nim wystarczająco mocne argumenty. Chętnie też uznają rację przeciwnika i bez oporów przyznają się do błędu. Nie wahają się dostrzegać i uwypuklać mocnych stron argumentacji na rzecz stanowiska przeciwnego, starają się do głębi rozumieć intencje przeciwnika i interpretować jego myśli w sposób najkorzystniejszy dla przyjętego przez niego stanowiska. Przedstawiają swoje argumenty, nie ukrywając ich niedociągnięć i nie stosując żadnych forteli mających sprawić wrażenie, że ich racje są mocniejsze, niż są naprawdę. Można powiedzieć, że głównym zwycięzcą takiej dyskusji ma być sama prawda ${ }^{10}$.

6. Na przeciwnym biegunie, w takim ujęciu, plasować się będzie dyskusja erystyczna, spór o cechach bezpardonowej walki, w której przeciwnicy dążą do obrony swoich stanowisk nawet kosztem prawdy, nie wahają się sięgać po kłamstwo, półprawdy, argumenty przekonujące i robiące wrażenie, choć $\mathrm{w}$ istocie bezwartościowe, kryjące w sobie zamaskowane błędy i obliczone na zmylenie przeciwnika. Rywale nie wykazują dobrej woli, nie cofają się przed podstępem i manipulacją, machinacjami wykorzystującymi bez skrupułów niewiedzę czy słabości charakteru przeciwnika. Stale obecna presja psychologiczna, manifestująca się napastliwym, szyderczym tonem, okazywaniem przeciwnikowi lekceważenia i pogardy, przerywaniem mu i niedopuszczaniem go do głosu, osobistymi wycieczkami, stanowi dopełnienie ponurego obrazu dyskusji erystycznej.

7. Mówiąc dalej o erystyce, będziemy mieli na myśli zespół metod wyodrębnionych mocą kryteriów nie etycznych, ale technicznych. Do erystyki należy więc wszystko to, co może być zastosowane w celu zyskania przewagi w sporze - zarówno przedstawianie mocnych logicznie argumentów, jak i argumentów z ukrytym błędem, mówienie prawdy i kłamstwo, odwoływanie się do racjonalności przeciwnika oraz oddziaływanie na jego wolę i uczucia. Czasem zwycięstwo odnosi się za pomocą przedstawiania konkluzywnego rozumowania, czasem poprzez zmylenie przeciwnika, wy-

8 Ibidem, s. 418.

${ }^{9}$ R. Ingarden: O dyskusji owocnej słów kilka. W: Idem: Książeczka o człowieku. Wydawnictwo Literackie, Kraków 1987, s. 171-176.

10 T. Kotarbiński: Logika dla prawników..., s. 419. 
warcie na niego psychologicznego wpływu itp. Czasem zwycięstwo będzie uczciwe, czasem nie, a czasem - jak twierdzimy - brak będzie podstaw do wydania obiektywnej oceny.

8. Wydaje się, że tłumaczenie skłonności erystycznych ludzi ich zepsutą naturą (por. opinia Schopenhauera w ustępie 4.) należy uznać za uproszczenie. Uporczywa walka o swoje racje wcale nie musi wynikać z obojętności na prawdę, przeciwnie, da się tłumaczyć jako rezultat szacunku do prawdy, mający jakieś racjonalne podstawy. Zauważmy najpierw, że pochopne przyznanie racji przeciwnikowi tylko dlatego, że w danej chwili nie potrafimy odeprzeć jego argumentu, sprzeciwia się dążeniu do prawdy. Przecież w nasze poglądy włożyliśmy pewien kapitał. Wypracowaliśmy je kosztem większego lub mniejszego wysiłku poznawczego, zostały wcześniej potwierdzone na różne sposoby, stanowią ogniwa naszego systemu przekonań, a usunięcie któregokolwiek z tych poglądów wiąże się z naruszeniem całej struktury. Racjonalne odrzucenie poglądu powinno więc mieć dostatecznie poważne powody. Jeśli jakiś argument zdaje się mu przeczyć, to na ogół rozsądniej jest przyjąć, że jest on wadliwy, a jedynie w danej chwili nie potrafimy rozpoznać błędu, niż odrzucić cenny element naszego systemu przekonań. Czyż kiedy ktoś przedstawi nam argument przeciw kulistości Ziemi, którego $\mathrm{w}$ danej chwili nie potrafimy obalić, to wtedy powinniśmy wyrzec się tego przekonania? Powstaje więc napięcie między z jednej strony twardymi regułami dyskusji wymagającymi, by wycofać stanowisko, którego nie potrafimy obronić, a z drugiej strony - racjonalnym przekonaniem, że $\mathrm{w}$ istocie nie mamy wystarczających podstaw do zwątpienia $\mathrm{w}$ jego słuszność. Psychologicznie zrozumiałe jest, że łatwiej przyjdzie nam łamać reguły dyskusji, niż - choćby tylko w ramach gry, którą jest dyskusja - udawać, że porzuciliśmy jakiś pogląd. Wtedy jednak łamanie zasad dyskusji wcale nie może być przypisywane pogardzie dla prawdy (oczywiście nie znaczy to, że w jakikolwiek sposób akceptujemy łamanie zasad dyskusji).

\section{Moralność a erystyka}

9. Jak wspominaliśmy, rozpowszechniony jest pogląd, że erystyka i jej metody są nieuczciwe, posługiwanie się nimi stanowi przejaw wypaczenia ludzkiej natury manifestujący się niepohamowanym, instynktownym pragnieniem, by nasza opinia wzięła górę nad innymi opiniami. Najprostsza nasuwa- 
jąca się odpowiedź na pytanie, na czym polega nieuczciwość erystyki, składałaby się prawdopodobnie $\mathrm{z}$ dwóch wobec niej zarzutów. Pierwszy byłby taki, że erystyka służy wprowadzaniu w błąd, raczej wykrzywia czy rozmywa prawdę, niż ją przybliża, podporządkowując tę wartość innym, mniej godnym wartościom. Weźmy na przykład flagowy erystyczny argument ad personam, czyli atak na osobę przeciwnika bez logicznego związku z jego argumentacją. Skutki użycia tej taktyki to powstrzymanie przeciwnika przed zgłoszeniem niewygodnego argumentu, zmiana tematu dyskursu - przeciwnik zaczyna bronić swojej osoby zamiast swojego stanowiska. Emocje, onieśmielenie czy wstyd mogą utrudnić adwersarzowi sprawne budowanie argumentów. Z kolei audytorium, ulegając efektowi aureoli (przekonaniu, że ohydny, śmieszny itp. człowiek nie może mieć racji), staje się uprzedzone do osoby przeciwnika, a więc $\mathrm{i}$ jego argumentów ${ }^{11}$. Jeśli więc ad personam da przewagę stosującej go stronie, to nie dzięki swojej logicznej sile, ale poprzez wpływ psychologiczny skutkujący zarówno błędną oceną rozumowań, jak i zablokowaniem prezentacji niewygodnych dla danej strony argumentów. Ad personam najwyraźniej więc sprzeciwia się skutecznemu rozpoznaniu prawdy. Sprecyzujmy: mówiąc dalej o „sprzeciwianiu się skutecznemu rozpoznawaniu prawdy”, będziemy mieć ogólnie na myśli działanie zmierzające do tego, by:

1) nie zostały przedstawione relewantne dane i argumenty;

2) błędnie zinterpretowano i oceniono dane i argumenty;

3) wprowadzić do dyskursu błędne (niesprawdzone, nieistotne, mylące) dane i wadliwe argumenty.

Przykładowo, kłamstwo i wygłaszanie argumentów z ukrytym błędem skutkuje 3. Oddziaływanie na emocje interlokutora czy też słuchaczy może powodować zarówno 1, jak i 2. Chwyt polegający na zmianie przedmiotu sporu (mutatio controversiae) powoduje 1 oraz 3 - zamiast przedstawiać istotne dane i argumenty, traci się czas i energię na rozpatrywanie nieważnych kwestii. Odpowiednio użyte machinacje semantyczne (na przykład ekwiwokacja) prowadzą do 2 i 3.

Kiedy dochodzi do $1-3$, powstaje zagrożenie, że przyczyną takiego, a nie innego rozstrzygnięcia sporu był brak kompletnych danych albo błędne rozpoznanie wartości argumentów. Skutkiem tego jest przyjęcie jakichś twierdzeń bez należytego uzasadnienia - stąd oskarżenie omawianej grupy chwytów erystycznych o utrudnianie rozpoznania prawdy i słuszności.

10. Sformułowaliśmy więc pierwszy zarzut wobec erystyki: sprzeciwia się ona prawdzie, jako że zmierza do któregoś z celów 1, 2 lub 3. Drugim punktem oskarżenia, pozostającym zresztą w ścisłym związku z pierwszym, będzie wskazanie manipulatorskiej natury erystycznych zabiegów. Mają

${ }^{11}$ T. Tyszka: Psychologiczne pułapki oceniania i podejmowania decyzji. Gdańskie Wydawnictwo Psychologiczne, Gdańsk 1999, s. 36-38. 
one często charakter podstępu, pułapki, nadużycia zaufania, zmierzają do wywarcia skrytego wpływu na oponenta czy słuchacza w taki sposób, by nie zdawał on sobie sprawy, co naprawdę jest przyczyną jego myśli, uczuć czy decyzji. W naszej kulturze postępowanie takie uważa się za nieetyczne i zwykle nazywa manipulacjąa ${ }^{12}$. Generalnie potępia się jako coś nieuczciwego wszelkie formy manipulacji, od najprostszych, jak kłamstwo, do tych bardziej wyrafinowanych.

\section{W obronie erystyki}

11. W poczynionych rozważaniach sformułowaliśmy zarzuty wobec erystyki - te, które się zwykle nasuwają, kiedy rzecz dotyczy jej moralnych aspektów. Już od starożytności zarzutom tym towarzyszą próby usprawiedliwienia jeśli nie samego uprawiania sztuki, to potrzeby jej nauczania i znajomości. Trudno odeprzeć zarzut nieuczciwości wobec erystyki, bo wydaje się niezaprzeczalne, że jej opanowanie ułatwia manipulatorstwo i odnoszenie zwycięstw wbrew prawdzie i słuszności. Niektórzy jednak bronią erystyki, wskazując na taki z niej pożytek, że uczy ona, jak rozpoznawać nieuczciwe chwyty i jak sobie $\mathrm{z}$ nimi radzić. Można w tym miejscu zauważyć, że niestety erystyka uczy również, jak radzić sobie z tymi, którzy rozpoznali nieuczciwy chwyt i próbują sobie z nim poradzić. Zauważmy też, że nie trzeba wcale stać się biegłym erystykiem, by umieć poradzić sobie z erystycznymi chwytami, podobnie jak umiejętność uchronienia się przed oszustwem nie wymaga wcale, byśmy zostali oszustami. Chyba dobra logika wystarczy, by obronić się przed naciąganymi argumentami. Lepszą być może linią obrony erystyki byłoby sławne porównanie walki na argumenty do sztuki walki na pięści, dokonane w Platońskim dialogu przez sofistę Gorgiasza (Gorgias, XI) ${ }^{13}$. Walczyć można skutecznie albo nieskutecznie niezależnie od tego, czy bronimy słusznej czy niesłusznej sprawy. Trudno winić nauczyciela sztuki skutecznej walki o to, jak wykorzysta ją uczeń.

12 I. Kamińska-Szmaj: Propaganda, perswazja, manipulacja - próba uporządkowania pojęć. W: Manipulacja w języku. Red. P. Krzyżanowski, P. Nowak. Wydawnictwo Uniwersytetu Marii Curie-Skłodowskiej, Lublin 2004, s. 13-27.

${ }^{13}$ Gorgiasza Platona cytuję za: Platon: Gorgias. W: Idem: Gorgias. Menon. Przeł., wstępem i komentarzem opatrzył P. Siwek. Wydawnictwo Naukowe PWN, Warszawa 1991, s. 7-132. 
Erystyka nakierowana jest właśnie na skuteczność: uczy, jak skutecznie osiągać cele, niezależnie jednak od tego, czy chodzi o cele godziwe czy nie. Niestety, wszelkie umiejętności i sprawności mogą służyć i dobru, i złu. Wykształcenie pedagogiczne ułatwia porywanie dzieci. Książka z zakresu kryminalistyki pouczy przestępcę, jak nie dać się złapać. To wszakże, że dana sprawność może być użyta $\mathrm{w}$ złych celach, nie stanowi wystarczającej racji, by zaniechać jej rozwijania. W tego rodzaju rozważaniach jednak brzmi fałszywy ton: być może i zależy nam na skuteczności, ale nie za wszelką cenę - nie za cenę podeptania norm przyzwoitości. Tymczasem erystyka wydaje się nie spełniać tego warunku - oferuje skuteczność, ale za cenę uczciwości.

12. Warto $\mathrm{w}$ tym miejscu porównać erystykę z retoryką, czyli sztuką przemawiania i konstruowania przekonujących mów. Nasuwa się refleksja, że wobec retoryki można z równą dozą słuszności wysunąć wszelkie te zarzuty, które wysuwa się wobec erystyki. Stosowane w tej sztuce typowe techniki mają charakter manipulacyjny i zmierzają do tych samych sprzeciwiających się prawdzie celów (1-3), o których mówiliśmy w ustępie 9. Retoryczne zabiegi służą wywołaniu u słuchaczy rozmaitych błędów poznawczych. Najprostszy i najpowszechniej stosowany chwyt we wszelkiego rodzaju mowach to selekcja informacji: mówca podaje wyłącznie te dane i argumenty, które sprzyjają jego stanowisku. Jeśli w ogóle wspomina o faktach niewygodnych, to tylko wtedy, gdy nie da się tego uniknąć, a i to zwykle w sposób nader tendencyjny i zwodniczo uproszczony. Oczywiście celem jest doprowadzenie słuchaczy do popełnienia tak zwanego błędu dostępności, kiedy to jednostka kształtuje swoją opinię, opierając się nie na kompletnym zestawie danych, ale na tym, co jest $\mathrm{w}$ danej chwili dostępne ${ }^{14}$. Audytorium, gdyby poznało wszystkie istotne dla sprawy okoliczności, wyrobiłoby sobie może inny pogląd - ale na skutek działań retora rozważyło tylko część całości, został więc zrealizowany cel 1 . Warto podkreślić, że dyskusja erystyczna korzystnie w tym miejscu odróżnia się od retoryki, ma bowiem wbudowaną naturalną zaporę przeciw selekcji informacji: niewygodne dla strony dane zawsze mogą być natychmiast przytoczone przez stronę przeciwną.

Innym charakterystycznym dla retoryki środkiem jest manipulacja językowa: używanie określeń nacechowanych emocjonalnie, dobór korzystnych określeń i porównan ${ }^{15}$ oraz figur retorycznych. Pewne treści przyjęte są nie ze względu na ich obiektywną wymowę, ale z powodu sposobu, w jaki je

${ }^{14}$ Por. R. Reber: Availability. W: Cognitive Illusions. A Handbook on Fallacies and Biases in Thinking, Judgement and Memory. Ed. R.F. Pohl. Psychology Press Taylor \& Francis Group, New York 2004, s. 147-164.

${ }_{15}$ Por. A. Schopenhauer: Erystyka, czyli sztuka prowadzenia sporów..., s. 61-62 (sposób 12). 
przedstawiono. Audytorium oceniłoby być może inaczej argument, gdyby sformułowano go w sposób neutralny językowo, nie użyto by eufemizmów, peryfraz, aluzji, ironii itp. Oznacza to, że wskazana grupa technik zmierza do 2.

Typowe dla retoryki jest oddziaływanie na uczucia audytorium: mówca stara się zaskarbić sobie sympatię słuchaczy, wprowadzić ich w odpowiedni nastrój, buduje odpowiednią aurę emocjonalną wobec przedmiotu perswazji ${ }^{16}$. Wpływanie na uczucia to najstarszy znany sposób manipulacji, stosowany między innymi w celu ukrycia błędów w argumentacji: odbiorca komunikatu uznaje argumenty nie dlatego, że są one logicznie bez zarzutu, ale dlatego, że wywołano u niego odpowiednie stany emocjonalne, co oznacza realizację celu 2 .

Wprowadzanie do dyskusji błędnych argumentów i danych (czyli 3) zależy od woli zarówno retora, jak i erystyka. Nie ma powodów, by sądzić, że sama natura którejkolwiek z tych sztuk w większym stopniu skłania jej użytkownika do stosowania takich metod albo też od ich stosowania go powstrzymuje.

13. Biorąc ustęp 12. pod uwagę, należałoby zadać pytanie: dlaczego w obiegowym pojęciu nieuczciwość jest definicyjną wręcz cechą erystyki, ale nie retoryki? Jeśli bowiem erystyka jest nieuczciwa, to za taką należałoby też bezwzględnie uznać retorykę. Arystoteles w Retoryce $(1355 \text { b5 })^{17}$ broni sztuki retoryki w sposób podobny do tego, jaki przedstawiliśmy w ustępie 11: „,zarzut, że można komuś wyrządzić wielką krzywdę, posługując się złośliwie potęgą wymowy, można postawić wszystkim innym dobrom [...]. Ich uczciwe wykorzystanie może przecież przynieść najwyższy pożytek, nieuczciwe natomiast - najbardziej zaszkodzić". Mirosław Korolko w rozdziale zatytułowanym Retoryka jako zespół etycznie neutralnych środków pisze: „Retoryka [...], nie będąca sama przez się celem, lecz narzędziem, jest zespołem środków etycznie neutralnych. Jest to jednak zbiór środków szczególnie niebezpiecznych, jeśli zostaną użyte do niegodziwych celów. [...] Retoryka może więc być użyta do poniżenia lub zniewolenia odbiorcy. Trzeba jednak pamiętać, że to nie retoryka poniża czy zniewala, lecz czyni to człowiek przekonujący za jej pomocą"18.

$\mathrm{Na}$ temat erystyki jej obrońca ma prawo rzec to samo, co napisaliśmy właśnie o retoryce. Jest to zbiór zasad skutecznego prowadzenia sporu: to nie erystyka krzywdzi, manipuluje, wprowadza w błąd, lecz człowiek ją

${ }^{16}$ M. Korolko: Sztuka retoryki. Przewodnik encyklopedyczny. Wyd. 2. rozsz. Wiedza Powszechna, Warszawa 1998, s. 72-73.

${ }^{17}$ Retoryke Arystotelesa cytuję za: Arystoteles: Retoryka; Retoryka dla Aleksandra; Poetyka. Przeł., wstępem i komentarzem opatrzył H. Podbielski. Wydawnictwo Naukowe PWN, Warszawa 2004.

${ }^{18}$ M. Korolko: Sztuka retoryki..., s. 40. 
stosujący. Można by oczywiście kontrargumentować, że retoryka w przeciwieństwie do erystyki ma w swoich zasobach metody, które czasami bywają użyte uczciwie, a czasami nie - to zależy od walorów moralnych samego mówcy. Erystyka natomiast miałaby być zbiorem chwytów niegodnych, których nigdy nie da się uczciwie użyć. Nie podzielamy takiego poglądu. Twierdzimy, że kto zarzuca erystyce stosowanie nieuczciwych metod przekonywania, powinien dokładnie to samo zarzucić retoryce.

14. Poświęcimy teraz nieco uwagi samemu problemowi podziału technik argumentowania i przekonywania - czy to $\mathrm{w}$ retoryce, czy w erystyce - na uczciwe i nieuczciwe. Trudno się nie zgodzić z twierdzeniem, że uczciwe albo nieuczciwe użycie danej techniki zależy nie tyle od niej samej, ile od okoliczności, w których ją zastosowano. Kłamstwo w wielu sytuacjach zasługuje na potępienie, ale przecież mało kto powie, że zasługuje na nie zawsze. Nieraz właśnie nieskłamanie to przejaw braku empatii i grubiaństwa. Mówiąc prawdę, można kogoś ciężko skrzywdzić. Bywa, że powstrzymanie się od kłamstwa jest uważane za zbrodnię, kiedy na przykład szczerze zdradzamy oprawcom miejsce pobytu ściganej ofiary. Nawet kłamanie wyłącznie w swoim interesie nie musi rodzić wątpliwości moralnych, choćby wtedy, kiedy ktoś kłamie, by nie zdradzać jakichś intymnych szczegółów, gdy wie, że prawda byłaby źle zrozumiana i uznana na przykład za kompromitującą go, gdy broni się przed doznaniem krzywdy. Chociaż więc kłamstwo ogólnie budzi u nas instynktowny moralny sprzeciw, to chyba większość zgodzi się na formułę, że choć kłamstwo często bywa czymś godnym potępienia, to nieraz użycie go zasługuje na pochwałę, nigdy jednak nie powiemy „,dobrze, że go okłamałeś”, ale raczej eufemistycznie „,dobrze, że nie powiedziałeś mu prawdy".

Podobnie jest $\mathrm{z}$ innymi typami manipulacji - w wielu wypadkach mielibyśmy za złe komuś to, że nie manipuluje. Ktoś, kto skutecznie pocieszył chorego przyjaciela, bez specjalnej dbałości o logiczną jakość swoich argumentów, nie wzbudza w nas odrazy - wręcz przeciwnie. Wyobraźmy sobie generała, który wygłaszając do żołnierzy mowę przed rozstrzygającą bitwą, przedstawia - gwoli zwykłej uczciwości - fakty i racje przemawiające na korzyść wroga. Pominięcie tych racji może przecież spowodować, że żołnierze uwierzą w słuszność sprawy, za którą mają przelewać krew, opierając się na niekompletnych danych (co wiąże się przynajmniej ze skutkiem 1, a czasami i 3). Czy naprawdę jednak generał postępuje nieuczciwie, przedstawiając żołnierzom sytuację w sposób tendencyjny, budując wątpliwe argumenty, apelując do emocji? Potoczna wiedza wskazuje, że nie musi się on obawiać oskarżenia o niemoralność. Przyjęte jest bowiem jako oczywiste, że lepiej jest, by żołnierskie morale - czynnik często rozstrzygający o wyniku bitwy - zbudowane było na niepełnej prawdzie czy wręcz na fałszu, 
niż żeby szanse wygranej spadły choćby nieznacznie z powodu mniejszej ofiarności i zapału targanych wątpliwościami żołnierzy. Oczywiście budzi w nas moralną odrazę obraz idących na śmierć, zmanipulowanych ludzi. Warto jednak uprzytomnić sobie wyraźnie alternatywę tego stanu rzeczy: oto broniących naszego kraju żołnierzy uczciwie poinformowano przed decydującym starciem, że szanse wygranej ze świetnie wyszkolonym i wyposażonym przeciwnikiem są raczej nikłe, zwłaszcza gdy się weźmie pod uwagę, że nasza kadra dowódcza jest mało doświadczona i nie można jej ufać, a nasi sprzymierzeńcy właśnie uciekli z pola bitwy.

Identyczne pytanie postawić możemy w odniesieniu do polityka naszej opcji, który mobilizując wyborców, wcale nie dba o to, by bezstronnie przedstawić dane i argumenty, a i często wysunie argument przekonujący tylko osoby o słabej zdolności krytycznego myślenia. Zapewne, mimo wszystko, nie będziemy mieć do niego pretensji. Mielibyśmy mu wręcz za złe, gdyby dokładał starań, by bezstronnie przedstawić sprawy. Przyjmujemy po prostu, że nie jest zadaniem mówcy obiektywna prezentacja materiału wraz z racjami za i przeciw, lecz nakłonienie wyborców do określonego zachowania. Chodzi nam o skuteczność i dalecy jesteśmy od troszczenia się o to, że wyborcy na skutek naszych działań podejmą decyzję, która obraża zasady racjonalności. Można wysunąć argument, że mówca pozwala sobie na tendencyjność, bo od tego jest druga strona sporu, by uzupełnić brakujące dane i odeprzeć wadliwe argumenty. Jeśli jednak przyjąć - odpowiemy - że obecność drugiej strony sporu zwalnia mówcę od obowiązku uczciwości, to co właściwie mamy do zarzucenia erystyce?

15. Powiedzmy wreszcie, że erystyka nie jest bynajmniej zbiorem chwytów godzących $\mathrm{w}$ zasady fair play, mających na celu wyłącznie promocję fałszu. Niektóre pouczenia erystyki, jak zauważa wspomniany przez nas w 11. Tadeusz Kotarbiński, nie mogą być zaliczone do arsenału zasad oszukańczej manipulacji ${ }^{19}$. Ponadto istnieje wiele takich manewrów, które wprawdzie mają manipulatorski charakter, ale jednocześnie sprzyjają trafnemu rozpoznaniu prawdy, dzięki czemu efektywnie wręcz przeciwdziałają zjawiskom 1-3. Stajemy wtedy przed paradoksalnym dylematem: czy w imię prawdy wolno manipulować? Za przykład manipulacji w imię prawdy może służyć chwyt polegający na ukrywaniu przed przeciwnikiem wniosku, do którego zmierzamy ${ }^{20}$. Przesłanki podajemy w taki sposób, by przeciwnik przyjął je, nie wiedząc, że chcemy z nich wyciągnąć korzystny dla siebie wniosek - gdyby wiedział, prawdopodobnie oszukańczo odmawiałby ich uznania. Zastosowany podstęp daje taką korzyść, że uniemoż-

19 T. Kotarbiński: Logika dla prawników..., s. 415-416.

${ }^{20}$ Por. A. Schopenhauer: Erystyka, czyli sztuka prowadzenia sporów..., s. 56-57, 59-60 (sposoby 4, 9, 10). 
liwia nieuczciwemu przeciwnikowi machinację polegającą na odrzuceniu istotnego argumentu pod pozorem, że opiera się on na niepewnych przesłankach. Mamy więc przykład erystycznej machinacji skierowanej przeciw innej erystycznej machinacji.

Rozpatrzmy fortel użyty przez Piotra w następującym dialogu:

Jan: Uważam, że psychologia jest taką dziwną nauką, która odkrywa rzeczy doskonale wszystkim znane i oczywistości te przedstawia jako wielkie naukowe osiągnięcia.

Piotr: Nie zgadzam się. Psychologia wcale nie głosi banałów. Czy wiesz na przykład, że psychologowie odkryli, że ludzie dobierają się w pary przeciwieństwami? Czy to jest dla ciebie oczywistość?

Jan: Oczywista oczywistość. Chyba nie znajdziesz wśród swoich znajomych kogoś, kto by o tym nie wiedział, że przeciwieństwa się przyciągają. A to dopiero wiekopomne odkrycie tej szacownej nauki...

Piotr: To dowiedz się, że psycholodzy wykazali, że to wcale nie jest prawda.

Piotr wprawdzie skłamał, ale dzięki temu osiągnął coś, co byłoby trudne albo niemożliwe do uzyskania bez odwołania się tego środka. Oto Jan jednoznacznie, w sposób niepozostawiający żadnych wątpliwości przyznał (choć wbrew swojej woli), że istnieją twierdzenia psychologii niestanowiące potocznych oczywistości.

Kiedy dokładniej przyjrzymy się strukturze typowej dyskusji, zauważymy, że każdy chwyt erystyczny może zostać w pewnych warunkach użyty zarówno w celu osiągnięcia napiętnowanych celów 1-3, jak i do przeciwstawienia się zmierzającemu do 1-3 przeciwnikowi. Techniki erystyczne są więc przydatne w zwalczaniu nie tylko rzetelnej argumentacji, lecz także innych technik erystycznych, w tym manipulacyjnych zapędów. Czasem więc posługujemy się fortelem, aby zdemaskować nieuczciwe, niekonstruktywne zachowanie przeciwnika. Bywa, że skutecznie powstrzymamy przeciwnika stosującego brudne metody, pokazując, że i my potrafimy w ten sposób boleśnie go ugodzić. Świadome użycie błędnego argumentu może spowodować, że przeciwnik, chcąc zdemaskować usterkę, będzie zmuszony do ujawnienia jakiejś istotnej, niekorzystnej dla siebie okoliczności. Kiedy jesteśmy zaskoczeni argumentem przeciwnika, możemy zyskać trochę czasu na obmyślenie dobrej odpowiedzi, kierując chwilowo wymianę zdań na boczne tory ${ }^{21}$ albo stosując metodę „potoku bezsensownych słów”22. Dzięki zastosowaniu takiego chwytu być może - z korzyścią dla prawdy - argument przeciwnika

\footnotetext{
${ }^{21}$ Ibidem, s. 73-75 (sposób 29).

${ }^{22}$ Ibidem, s. 85-85 (sposób 36).
} 
zostanie racjonalnie odparty. Tak więc techniki erystyczne są czasem wykorzystywane $\mathrm{w}$ celach godziwych, czasem w celach niegodziwych - i warto zauważyć, że nierzadko bardzo trudno wydać jednoznaczną moralną ocenę konkretnego zastosowania chwytu $\mathrm{w}$ danej sytuacji, a ferowanie kategorycznych wyroków „uczciwy” - „nieuczciwy” jest nieuprawnione. Jest wiele technik erystycznych, które z jednej strony mają charakter niezaprzeczalnie manipulatorski, polegają bowiem na skrytym wywieraniu wpływu na przeciwnika, wykorzystaniu jego niewiedzy czy nieuwagi, z drugiej strony zaś - użyte sprzyjają rozpoznaniu prawdy. Nawet jednak wtedy, gdy zastosujemy chwyt prowadzący do 1-3, ważnym kryterium bywa wysokość stawki, o którą toczy się spór. Wrócimy do tego zagadnienia w kolejnym rozdziale.

\section{Erystyka i wojna}

16. Istnieje $w$ językach europejskich bogata metaforyka ujmująca spór i argumentację w kategoriach walki czy też wojny. Strony w sporach słownych atakuja, bronia się, zajmuja pozycje, sq na straconych pozycjach, wycofuja się, wciagaja $w$ zasadzkę, oddaja pole, sięgaja po nowa broń itd. Tadeusz Kotarbiński ${ }^{23}$ rozpatruje erystykę po prostu i dosłownie jako rodzaj walki - pokazuje, jak kategorie ogólnej teorii walki da się stosować do walki na argumenty, co pozwala zobaczyć, jak silnymi analogiami jest wsparta wspomniana metaforyka. Odejdziemy jednak od zagadnień taktyki i strategii, na których koncentruje się Kotarbiński, i zwrócimy uwagę na inne jeszcze podobieństwa między sztuką wojenną a erystyką.

17. Typowe dla wojen jest to, że ich tłem jest różnica zdań na temat tego, co słuszne, wraz ze stanowczą wolą stron zrealizowania swoich zamierzeń za wszelką cenę. Zwykle wojna wybucha wtedy, gdy nie ma innego sposobu zażegnania konfliktu interesów: konieczność zwycięża z moralnością. Podobnie jak w dyskusji erystycznej, prawda i słuszność są na pozór dla wojujących stron istotne i - gdyby im wierzyć - stanowią wręcz motor ich poczynań. Podobnie jak to bywa w erystyce, owa „prawda” i „słuszność” są na wojnie do cna zdominowane interesem własnym i zawsze doskonale z nim zgodne. Jeśli chodzi o ocenę samych działań wojennych, to kategorie moralne są do nich stosowane w bardzo ograniczonym zakresie. Nie słyszano

${ }^{23}$ T. Kotarbiński: L'éristique - Cas particulier de la théorie de la lutte. „Logique et Analyse" 1963, vol. 6, n 21/24, s. 19-29. 
chyba, by jakiś wódz spotkał się z zarzutem, że wygrał bitwę nieuczciwe. Zmylenie przeciwnika, wciągnięcie go w pułapkę, zastraszenie, zdrada - to uznane metody, których słuszności moralnej nikt nawet nie analizuje. Gra nie fair to na wojnie wręcz cnota. Inter arma silent leges (Cyceron) - w czasie wojny ludzie robią rzeczy, których zabraniają kodeksy moralne i które w zwykłych warunkach są surowo zakazane, ścigane przez prawo. Już zresztą w czasie pokoju żołnierze są uczeni tego, jak na przykład przebić bagnetem człowieka. Nie uważa się jednak tego za nieetyczne ze względu na świadomość, że wojna zmusza do takiego postępowania. Zasad moralnych wojna całkowicie wszakże nie wygasza, potępiane są choćby działania prowadzące do niepotrzebnych ofiar czy też przysparzające zbędnych cierpień żołnierzom i cywilom. Pogwałcenie nawet najoczywistszych zasad czasem wszakże nie spotyka się z potępieniem, o ile miało charakter instrumentalny, było podporządkowane celom strategicznym.

Odnotujmy jeszcze jeden aspekt wojny: strona może być w nią uwikłana wbrew swojej woli i najszczerszej chęci. Kraj napadnięty musi się bronić, nieraz konieczne jest uderzenie wyprzedzające na wroga tuż przed planowanym przez niego atakiem, bo bez tego czeka nas klęska. Czasem znowu musimy atakować, by wypełnić zobowiązania sojusznicze. W przypadku wojny prewencyjnej napadamy na inny, agresywny i rosnący w potęgę kraj, bo jeśli tego nie zrobimy, to on na pewno za kilka lat nas zmiażdży swoją przewagą.

18. Wojna nie jest podobna do walki na argumenty pod jednym względem: wynik wojny nie ma żadnego logicznego związku z prawdziwością twierdzeń głoszonych przez strony. Najwspanialsze zwycięstwo w żaden sposób nie upoważnia do wniosku, że triumfator miał rację, sromotna przegrana nie świadczy o tym, że pokonany był w błędzie (chociaż prawdopodobnie myśl „wygraliśmy, co oznacza, że nie myliliśmy się" nawiedza niektóre nieskomplikowane umysłowości). W bitwie erystycznej natomiast jest inaczej. Erystyka jest wprawdzie niedoskonałym narzędziem poszukiwania prawdy, wynik zmagań jednak może mieć niejaki związek z obiektywnym stanem rzeczy. Czasem ten związek jest dość luźny, ale w wielu wypadkach całkiem rozsądnie jest przyjąć, że pogląd broniony przez zwycięzcę jest tym lepiej uzasadnionym.

19. Wojna dostarcza modelu dla tych interakcji społecznych, które są małymi wojnami właśnie, rządzą się mechanizmami wojennymi i rodzą dylematy podobne do tych, które rodzi wojna, choć zwykle w skali mikro. Czynimy coś, co w myśl konwencjonalnych zasad moralnych (na przykład „,nie kłam”) jest niedopuszczalne, a powodem tego nie musi być nasza moralna nędza, lecz - konieczność. Jesteśmy wbrew swojej woli wciągnięci w tryby machinacji wojennych, gdzie łamie się pewne zasady, a jeśli my 
nie będziemy ich łamać, to ucierpi na tym sprawa, której bronimy. Ocena zaś, czy waga danej sprawy usprawiedliwia naruszanie zasad w takim czy innym zakresie, jest bardzo trudna, a niekiedy niemożliwa.

Rozważmy taki oto przykład. Kandydat na prezydenta w czasie telewizyjnej debaty musi odeprzeć wyjątkowo trudny argument przeciwnika dotyczący węzłowego punktu programu tegoż kandydata. Niestety, nie znajduje żadnego rzetelnego kontrargumentu. Rzecz dotyczy złożonej kwestii, nad której wyświetleniem pracowali wybitni eksperci, potrzebna jest specjalistyczna wiedza, której debatujący kandydat nie posiada. Jest on wprawdzie pewien, że jego eksperci z łatwością obaliliby argument, sam jednak tego uczynić nie potrafi. Ma do wyboru dwie opcje. Pierwsza to użycie „nieuczciwego”, erystycznego chwytu w celu zmiany tematu, zignorowania kłopotliwego argumentu czy zneutralizowania go w inny sposób; druga to „uczciwe" przyznanie, że jest się wobec argumentu bezradnym, razem $\mathrm{z}$ ewentualnymi wyjaśnieniami o złożonym charakterze problemu, które to wyjaśnienia $\mathrm{w}$ oczach widowni będą oczywiście tylko niezdarnymi wykrętami. Wybierając drugą opcję, polityk wprowadziłby w błąd obserwujących debatę wyborców - myślą oni w sposób uproszczony i nie analizują wszystkich aspektów problemu, dla nich sprawa jest jasna i bezsporna: skoro kandydat sam przyznaje, że nie wie, co powiedzieć, to z jego programem naprawdę musi być coś nie tak. Która z dwóch opcji jest lepsza? Czy ta „uczciwa”?

20. Święty Mateusz w jednym z rozdziałów Ewangelii (Mt 22,15-22) przedstawia zaplanowany przez faryzeuszy podstęp mający zaszkodzić Jezusowi. Występują do niego z udawaną pokorą, prosząc o rozstrzygnięcie kwestii: czy należy płacić podatki Rzymowi? Jak wiemy, Rzymianie byli znienawidzonymi przez Żydów okupantami ich kraju. Kalkulacja faryzeuszy była taka: jeśli Jezus powie, że nie powinno się płacić podatków Rzymowi, będzie mógł być oskarżony przed władzami rzymskimi o nielojalność i wichrzycielstwo, jeśli zaś powie, że podatki należy płacić, sam zdyskredytuje się w oczach ziomków Żydów jako rzymski lojalista. Jezus reaguje w następujący sposób: „«[...] Pokażcie Mi monetę podatkową!» Przynieśli Mu denara. On ich zapytał: «Czyj jest ten obraz i napis?» Odpowiedzieli: «Cezara». Wówczas rzekł do nich: «Oddajcie więc Cezarowi to, co należy do Cezara, a Bogu to, co należy do Boga». Gdy to usłyszeli, zmieszali się i zostawiwszy Go, odeszli” (Mt 22,19-22)24. Nie sposób zaprzeczyć, że Jezus użył tutaj chwytu erystycznego w pełnym tego słowa znaczeniu: zręcznie uchylił się od jednoznacznej odpowiedzi na kłopotliwe pytanie, w dodatku sugerując, że

${ }^{24}$ Cytaty z Biblii za: Biblia Tysiaclecia. Pismo Święte Starego i Nowego Testamentu. $W$ przekładzie z języków oryginalnych. Oprac. zespół biblistów polskich z inicjatywy Benedyktynów Tynieckich. Wyd. 4. Pallotinum, Poznań 1991. 
jego odpowiedź wynika z faktu, że na monecie są rzymskie symbole, która to okoliczność jest przecież bez znaczenia. Faryzeusze, nawiasem mówiąc, łatwo dali za wygraną, mogli powiem dopytywać: „To mamy płacić te podatki czy nie?". Czy Jezus postąpił niemoralnie, używając na swojej wojnie z faryzeuszami wybiegu erystycznego? Trzeba rozważyć sytuację, w której się znalazł. Musiał oto dokonać wyboru między takimi opcjami:

1) konflikt $\mathrm{z}$ bezwzględnymi władzami rzymskimi, bardzo wyczulonymi na sprawę płacenia podatków;

2) utrata twarzy w oczach Żydów, a co za tym idzie, konieczność rezygnacji ze swojej misji nauczycielskiej;

3) zastosowanie niekrzywdzącego nikogo wybiegu erystycznego, a przy okazji wygłoszenie bogatej w treść maksymy.

21. W szczególnej sytuacji znajdują się politycy w krajach demokratycznych, biorący udział $\mathrm{w}$ permanentnej walce o władzę. Polityk musi przekonać wyborców, że to on, a nie któryś z jego konkurentów, powinien objąć stanowisko burmistrza, posła, senatora, prezydenta. Napotyka w tym na poważny problem: wie, że jeśli będzie grał fair, to jego szanse na wybór spadną do zera, a to $\mathrm{z}$ tego powodu, że jego konkurenci na pewno nie będą grali fair. A znowu ci konkurenci, trzeba powiedzieć, będą grali nie fair niekoniecznie dlatego, że są złymi, zdeprawowanymi ludźmi, ale dlatego, że wiedzą, że w przeciwnym wypadku ich szanse na wybór spadną do zera, bo na pewno ich konkurenci nie będą grać czysto. Przykładowo, uczciwy polityk być może chciałby lojalnie powiedzieć wyborcom, że jego program gospodarczy ma pewne wady (jak wszystko na tym świecie zresztą), ale wie dobrze, że jego konkurenci nie zdradzą wyborcom żadnych słabych stron swoich programów. Stoi więc uczciwy polityk przed dylematem - albo zatai prawdę czy wręcz okłamie wyborców, albo przegra wybory i nie będzie mógł wprowadzić w życie dobrych pomysłów gospodarczych obmyślanych przez wybitnych specjalistów. Niestety, gra wyborcza jest pewnego rodzaju pułapką społeczną wymuszającą na uczestnikach równanie w dół: kto próbuje równać $\mathrm{w}$ górę, wypada $\mathrm{z}$ gry. Sytuacja przypomina pojedynek rewolwerowców w westernach: jeśli nie strzelisz pierwszy, to przeciwnik pierwszy strzeli do ciebie. Strzelasz więc nie dlatego, że chcesz przeciwnika zabić - w istocie bardzo tego nie chcesz - ale dlatego, że jeśli nie strzelisz, on zabije ciebie.

22. Pułapka społeczna to znane i szeroko opisywane w literaturze zjawisko ${ }^{25}$. Jednostki, grupy lub organizacje nie są w stanie owocnie współpracować ze względu na wzajemną nieufność i brak kapitału społecznego, nawet tam, gdzie współpraca przyniosłaby zdecydowane korzyści wszystkim.

${ }^{25}$ E. Hankiss: Pułapki społeczne. [Z węg. tłum. T. Kulisiewicz]. Wiedza Powszechna, Warszawa 1986. 
Szczególnym przypadkiem pułapki społecznej, podobnym do rozważanych już tutaj zjawisk, jest rozpatrywany w teorii gier dylemat więźnia ${ }^{26}$. Wszyscy gracze $\mathrm{w}$ konfliktowej grze wybierają strategię dominującą i właśnie ten wybór prowadzi do wyniku, który jest dla wszystkich najgorszy z możliwych. Przewidując, że rywale będą grać nieczysto, i my nie przebieramy w środkach. W rezultacie walka polityczna staje się polem najpodlejszych manipulacji. Z całą pewnością sytuację pogarsza mechanizm traktowania bezpardonowych zagrań strony przeciwnej jako czegoś wymagającego stosownej odpłaty i rewanżu. Zemsta rodzi potrzebę zemsty, wyniki badań psychologicznych zaś sugerują istnienie u ludzi skłonności do eskalowania zemsty: wymierzania „kary” o natężeniu znacznie przewyższającym stopień „,winy" ${ }^{27}$. Niestety, wydaje się, że w przypadku demokratycznej gry o władzę nie da się zastosować opisywanych w literaturze standardowych metod radzenia sobie z pułapkami społecznymi. Są jednak podstawy do mniemania, że owo opisane wymuszone przez system demokratyczny równanie w dół ma swój kres, wytyczony przez umysłowość i postawę obywatelską wyborców. Im większa jest ich wiedza, kultura ogólna, a w szczególności umiejętność krytycznego myślenia i znajomość erystyki (!), tym mniejsze pole do działania dla manipulacji - tym mniej nieuczciwi politycy mogą, a uczciwi muszą manipulować. Można rzec, że tyle jest demagogii i populizmu w demokratycznej walce politycznej, na ile pozwalają kwalifikacje umysłowe i moralne obywateli oraz ich zaangażowanie. W opinii piszącego te słowa manipulację ograniczyć można jedynie przez podniesienie kwalifikacji wyborców, stworzenie sytuacji, w której polityk musi się obawiać, że manipulując, skompromituje się w ich oczach.

\section{Zakończenie}

23. Na koniec warto podkreślić, że wygłoszonych twierdzeń nie należy traktować jako wyrazu amoralizmu autora i nawoływania do tego, by powstrzymać się od oceniania kłamstwa i manipulacji w kategoriach moralnych. Wręcz przeciwnie, wrażliwość moralna i oceny etyczne mają

${ }^{26}$ Ph.D. Straffin: Teoria gier. Tłum. J. Haman. Wydawnictwo Naukowe „Scholar”, Warszawa 2001, s. 94-108.

${ }^{27}$ S.S. Shergill et al.: Two Eyes for an Eye: The Neuroscience of Force Escalation. „Science” 2003, vol. 301, s. 187. https://doi.org/10.1126/science.1085327. 
olbrzymie znaczenie - i dlatego jest tak ważne, by nasze osądy były racjonalne i adekwatne, ściśle dostosowane do struktury ocenianych sytuacji. Bez rozważenia kontekstu, wchodzących z sobą w kolizję wartości oraz rozmaitych uwarunkowań osób, których działania oceniamy, łatwo o krzywdzące uproszczenia i niesprawiedliwość. Erystykę należy rozpatrywać w zwykłym kontekście społecznym, w którym prawda nie jest jedyną wartością ani też wartością najwyższą. Wprawdzie pożądamy prawdy, ale nie tylko prawdy. Nieraz nie da się osiągnąć różnych celów jednocześnie i musimy dokonać wyboru. Jest to $\mathrm{w}$ życiu społecznym czymś zwykłym i nieuniknionym. Nieraz kłamiemy właśnie w interesie prawdy, a nieraz musimy prawdę ograniczyć czy wykrzywić, by osiągnąć jakieś ważniejsze od niej cele. W prawie sądowym znane i stosowane są zasady pozwalające za podstawę wyroku przyjąć prawdę formalną, która niemal na pewno rozmija się $\mathrm{z}$ prawdą w zwykłym tego słowa znaczeniu. W takich wypadkach ponad prawdę przedkłada się inne wartości: sprawiedliwość czy też możliwość rozsądnego rozstrzygnięcia sporu. Erystyka funkcjonuje właśnie w takim środowisku, stanowiąc narzędzie interakcji społecznych, którego użyteczność zależy od cech całej struktury, w której operuje.

Znajomość erystyki, zarówno w wymiarze teoretycznym, jak i praktycznym, to ważna kompetencja społeczna, choć oczywiście jej nadużywanie powinno spotkać się z jednoznacznym potępieniem.

\section{Bibliografia}

Arystoteles: Dzieła wszystkie. T. 1: Kategorie; Hermeneutyka; Analityki pierwsze; Analityki wtóre; Topiki; O dowodach sofistycznych. Przekł., wstępy i komentarze

K. Leśniak. Wyd. 2. Wydawnictwo Naukowe PWN, Warszawa 2003.

Arystoteles: Retoryka; Retoryka dla Aleksandra; Poetyka. Przel., wstępem i komentarzem opatrzył H. Podbielski. Wydawnictwo Naukowe PWN, Warszawa 2004. Biblia Tysiaclecia. Pismo Święte Starego i Nowego Testamentu. W przektadzie z języków oryginalnych. Oprac. zespół biblistów polskich z inicjatywy Benedyktynów Tynieckich. Wyd. 4. Pallotinum, Poznań 1991.

Hankiss E.: Pułapki społeczne. [Z węg. tłum. T. Kulisiewicz]. Wiedza Powszechna, Warszawa 1986.

Ingarden R.: O dyskusji owocnej stów kilka. W: Idem: Ksiażeczka o człowieku. Wydawnictwo Literackie, Kraków 1987, s. 171-176. 
Kamińska-Szmaj I.: Propaganda, perswazja, manipulacja - próba uporządkowania pojęć. W: Manipulacja w języku. Red. P. Krzyżanowski, P. Nowak. Wydawnictwo Uniwersytetu Marii Curie-Skłodowskiej, Lublin 2004, s. 13-27.

Korolko M.: Sztuka retoryki. Przewodnik encyklopedyczny. Wyd. 2. rozsz. Wiedza Powszechna, Warszawa 1998.

Kotarbiński T.: L'éristique - Cas particulier de la théorie de la lutte. „Logique et Analyse" 1963, vol. 6, n 21/24, s. 19-29.

Kotarbiński T.: Ontologia, teoria poznania i metodologia nauk. Zakład Narodowy im. Ossolińskich, Wydawnictwo, Wrocław 1993.

Platon: Gorgias. W: Idem: Gorgias. Menon. Przeł., wstępem i komentarzem opatrzył P. Siwek. Wydawnictwo Naukowe PWN, Warszawa 1991, s. 7-132.

Reber R.: Availability. W: Cognitive Illusions. A Handbook on Fallacies and Biases in Thinking, Judgement and Memory. Ed. R.F. Pohl. Psychology Press Taylor \& Francis Group, New York 2004, s. 147-164.

Schopenhauer A.: Erystyka, czyli sztuka prowadzenia sporów. Przeł. z niem. B. Konorski, Ł. Konorska. Przedmowa T. Kotarbiński. Wydawnictwo Literackie, Kraków 1973.

Shergill S.S. et al.: Two Eyes for an Eye: The Neuroscience of Force Escalation. „Science” 2003, vol. 301, s. 187. https://doi.org/10.1126/science.1085327.

Spranzi M.: The Art of Dialectic between Dialogue and Rhetoric: The Aristotelian Tradition. John Benjamins Publishing Company, Amsterdam-Philadelphia 2011.

Straffin Ph.D.: Teoria gier. Tłum. J. Haman. Wydawnictwo Naukowe „Scholar”, Warszawa 2001.

Tyszka T.: Psychologiczne pułapki oceniania i podejmowania decyzji. Gdańskie Wydawnictwo Psychologiczne, Gdańsk 1999.

Walton D.: Dialog Theory for Critical Argumentation. John Benjamins Publishing Company, Amsterdam 2007.

Krzysztof Szymanek - doktor habilitowany, profesor Uniwersytetu Śląskiego w Katowicach, zatrudniony w Instytucie Filozofii Uniwersytetu Śląskiego w Katowicach. 